\title{
Meesmann Corneal Dystrophy
}

National Cancer Institute

\section{Source}

National Cancer Institute. Meesmann Corneal Dystrophy. NCI Thesaurus. Code C84795.

An autosomal dominant inherited corneal disorder caused by mutations in the KRT 3 and KRT 12 genes. It is characterized by the formation of multiple tiny cysts in the epithelial layer of the cornea. The cysts may rupture, causing pain, redness and light sensitivity. Vision usually is not affected. 